\title{
Effects of methanol extract of bark of Bauhinea purpurea on alcohol-induced liver toxicity in albino rats
}

\author{
Chaturvedi PADMAJA \\ Department of Biological Sciences University of Botswana Gaborone, Botswana Pvt Bag 0022. \\ Corresponding author, Email: chaturve@mopipi.ub.bw
}

\begin{abstract}
The present study has been aimed to evaluate the protective potential of methanol bark extract of Bauhinia purpurea (MBP) in albino rats against alcohol-induced hepatotoxicity. Rats were randomly divided into four groups; alcohol control group (AC) receiving alcohol $(5 \mathrm{~g} / \mathrm{kg}$ ), normal control group (NC) that received distilled water, and two experimental groups (E1 and E2) that were administered two doses of methanol extract (50 and $100 \mathrm{mg} / \mathrm{kg}$ body weight) for 30 days. At the end of the experiment, rats were killed after ether anesthesia and liver and blood were collected for biochemical measurements. Parameters measured were thiobarbituric acid reactive substances (TBARS), serum glutamate oxaloacetate transaminase, serum glutamate pyruvate transaminase, reduced glutathione, glutathione peroxidase, superoxide dismutase, catalase and ascorbic acid. Methanol extract inhibited lipid peroxidation as indicated low levels of thiobarbituric acid. Low levels in the activities of serum aspartate aminotransferase (AST) and serum alanine aminotransferase (ALT) in experimental animals demonstrated the protective effects of MBP from hepatic toxicity. It also maintained the levels of enzymatic and non-enzymatic antioxidants in dose dependant manner.
\end{abstract}

(C) 2011 International Formulae Group. All rights reserved.

Keywords: Lipid peroxidation, anti-oxidants, glutathione, ascorbic acid.

\section{INTRODUCTION}

Alcohol abuse is one of the major problems in African continent and is responsible for significant percentage of hospital admission. Oxidative stress plays a significant role in the development of alcohol induced tissue damage and is generally considered as an imbalance between proxidant and antioxidant systems. The major destructive effect is the initiation of lipid peroxidation leading to the destruction of cellular membrane causing leakage of lysosomal enzyme and subsequent autolysis (Firdous, 2011). Various pathways play a significant role in ethanol induced tissue injury, including changes in cellular oxidized $\mathrm{NAD}+, \mathrm{NADH}$ and production of acetaldehyde protein adducts (Lieber, 2004). It also induces production of CYP2E1 formation of 1-hydroxyethyl free radicals ethanol mediated mitochondrial damage (Knockaert, 2011). Thus toxic effects of ethanol are attributed to increased generation of these free radicals after alcohol metabolism. Liver is the central organ for extensive metabolism and detoxification. Metabolism of alcohol leads to the damage of liver and other vital organs because of chain 
reaction of lipid peroxidation (Jeannot, 2011). Therefore inhibition of free radicals generation is important in providing protection against hepatic damage. Plants are natural source of antioxidants that reduce oxidative stress. Recent awareness regarding the therapeutic uses of several traditionally used plants has opened a new era in the field of research of medicinal plants. In African and Indian traditional medicine, several medicinal plants have been used to treat liver diseases.

Bauhinea purpurea commonly known as Kachnar in India, is one of the plants used in Ayurvedic system of medicine (Ambast, 1998). B. purpurea is worldwide in distribution although it is a native plant of Southeastern Asia ranging from India up to China. It is also found in Botswana as ornamental tree in gardens and on the road side. It is a fast growing small to medium size tree, approximately $7.6 \mathrm{~m}$ in height and 17.8 $\mathrm{cm}$ in diameter. Flowers are light purple in color and borne on unbranched axillaries or terminal corymbs in winter and autumn. In Botswana it is used to increase the appetite and also as liver tonic. The bark of this tree is widely used in the Ayurvedic system of medicine for the treatment of liver and thyroid disorders (Kirtikar and Basu, 2001). Modern reports also support the thyrogenic effects of the plant (Panda and Kar, 1999). Antinociceptive, anti-inflammatory and antipyretic properties of the aqueous extract of B. purpurea leaves in experimental animals has been reported by Zakaria et al. (2007). Phytochemical studies on B. purpurea has also been reported for its richness in phenol content (Sharanabasappa et al., 2007). The oil of the seed of $B$. purprea has been demonstrated to possess phytosterols; betasitosterol and stigmasterol, and betatocopherol. Bauhinea variegate bark extract exhibited the hepatoprotective properties against carbon tetrachloride-induced oxidative stress in albino rats (Bodakhe et al., 2007). Antioxidant activities and free radical scavenging potential of Bauhinea microstachya has been attributed to its rich polyphenol content (Silva et al., 2007). Many other species of Bauhinea have also been shown to demonstrate antioxidant and free radical scavenging activities (Nageswar et al., 1986).

Since other related species have been reported for their antioxidant and hepatoprotective effects, and in Botswana this species is used as liver tonic and appetite enhancer, it is postulated that there is a possibility that $B$. purpurea might be possessing hepatoprotective properties. Therefore, the present study was planned with an aim to evaluate the hepatoprotective potentials of methanol extract of stem bark against alcohol induced toxicity.

\section{MATERIALS AND METHODS}

\section{Collection of plant material and} preparation of extract

The plant was identified by Dr. M. P. Setshogo, senior lecturer in the Botany Section of the Department of Biological Sciences, University of Botswana, Botswana. Bark of the tree was collected from University Campus, washed, chopped into small pieces and shed dried. After that it was crushed to powder and soaked with $70 \%$ methanol for cold extraction. The extract was filtered after seven days and made solvent free after evaporating it under reduced pressure. The yield of the extract was $7.8 \% \mathrm{w} / \mathrm{w}$.

\section{Experimental animals}

Twenty male albino SD rats of approximately $200 \mathrm{~g}$ weight were used for all experiments. Initial weights of all the rats were recorded. They were housed in colony cages at an ambient temperature of $25{ }^{\circ} \mathrm{C} \pm 2$ ${ }^{\circ} \mathrm{C}$ with 12 Hours cycle of light darkness. Animals had free access to water ad libitum and were fed on commercial diet bought from Nola Food Corporation, South Africa. Experiment was conducted as per internationally accepted principles for laboratory animal care Unit, Department of Biology, University of Botswana and permission to perform this experiment on 
albino rats was obtained from ministry of communication science and technology (CST 16/9 III(25)).

\section{Acute toxicity study}

Animals were orally administered different doses between $50 \mathrm{mg} / \mathrm{kg}$ - 500 $\mathrm{mg} / \mathrm{kg}$ and were observed for 24 hours for behavioral change like general activity, sedation, convulsion and mortality. Two doses 50 and $100 \mathrm{mg} / \mathrm{kg}$ body weight were selected for the study.

\section{Experimental design}

Twenty rats were used for this experiment and were divided into four groups of five each:

- Group NC: normal control group received distilled water,

- Group AC: alcohol control group received alcohol ( $5 \mathrm{~g} / \mathrm{kg})$ every day,

- Group E1: experimental group received the plant extract $(50 \mathrm{mg} / \mathrm{kg})$ plus alcohol $(5 \mathrm{~g} / \mathrm{kg})$, - Group E2: experimental group received the plant extract $(100 \mathrm{mg} / \mathrm{kg})$ plus alcohol (5 $\mathrm{g} / \mathrm{kg}$ ).

The experiment was run for 30 days. All the administration was oral and done with the help of syringe and tube. At the end of the experiment, the final body weight of all the rats were recorded and were killed by decapitation after ether anesthesia. Blood was collected from brachial artery, plasma was separated from it and frozen $\left(-70{ }^{\circ} \mathrm{C}\right)$. The liver was collected and washed with cold normal saline. This was also frozen at $-70^{\circ} \mathrm{C}$ for estimation of biochemical parameters.

\section{Biochemical measurements}

\section{Thiobarbituric acid reactive substances}

Thiobarbituric Acid Reactive

Substances (TBARS) in plasma was estimated by the method described by Tripathi et al. (2001). Plasma or liver homogenate $(0.1 \mathrm{ml})$ was treated with $2 \mathrm{ml}$ of TCA-TBA-HCL (TBA $0.37 \%, 0.25 \mathrm{~N} \mathrm{HCl}$ and $15 \%$ TCA) reagent $(1: 1: 1)$ and incubated in boiling water bath for 10 minutes, the mixture was cooled and mixed with $2 \mathrm{ml}$ of freshly prepared $1 \mathrm{~N}$ $\mathrm{NaOH}$ and absorbance measured at $535 \mathrm{~nm}$.

Serum aspartate aminotransferase (AST), serum alanine aminotransferase (ALT) and total protein

Methods described in kits (Agape

Diagnostics) were followed.

\section{Reduced glutathione}

Reduced Glutathione (GSH) level was measured by the method of Ellman (1959). $0.25 \mathrm{ml}$ of liver homogenate was mixed with $0.5 \mathrm{ml}$ of precipitating buffer $(1.67 \mathrm{~g}$ Metaphosphoric acid, $0.2 \mathrm{~g}$ EDTA, $30 \mathrm{~g}$ sodium chloride dissolved in $100 \mathrm{ml}$ of double distilled water) and centrifuged. Supernatant was collected and mixed with $2.5 \mathrm{ml}$ of $0.3 \mathrm{M}$ phosphate buffer. Colour was developed by adding $100 \mu \mathrm{l}$ of $0.01 \%$ 5,5-dithiobis 2nitrobenzoic acid (DTNB) and read at 412 $\mathrm{nm}$.

\section{Super oxide dismutase}

Superoxide dismutase level was measured by the method of Kakkar et al. (1984). The reaction mixture consisted of $150 \mu \mathrm{l}$ EDTA $(0.5 \mathrm{mmol}), 600 \mu \mathrm{l} \mathrm{L}-$ methionine $(130 \mathrm{mmol})$ and $300 \mu \mathrm{l} \mathrm{NBT}$ (750 $\mu \mathrm{mol})$. The volume of reaction mixture was made up $2.8 \mu 1$ with SOD buffer. Then $200 \mu$ l of sample liver homogenate was added except in the control. Finally, $200 \mu \mathrm{l}$ of riboflavin was added to start the reaction. All the test tubes were placed under fluorescent lamp except the blank. Absorbance was recorded at $540 \mathrm{~nm}$ after 4 minutes. One unit of enzyme activity was calculated as the activity that was required to inhibit the reduction of NBT by $50 \%$.

\section{Glutathione peroxidase}

Activity of glutathione peroxidase was measured using the method described by Paglia (1967). To $1 \mathrm{ml}$ of phosphate buffer were added : $200 \mu$ l EDTA, $200 \mu \mathrm{l} \mathrm{GSH,} 200$ $\mu \mathrm{l}$ of sodium azide, $200 \mu \mathrm{l}$ of $\mathrm{H}_{2} \mathrm{O}_{2}, 200 \mu \mathrm{l}$ of $\mathrm{NADPH}$, one unit of glutathione reductase 
and an appropriate amount of the sample (100 $\mu 1)$. The decrease in absorbance due to NADPH oxidation was monitored at $340 \mathrm{~nm}$ for 3 minutes. Glutathione peroxidase activity was calculated using the extinction coefficient of NADPH $\left(6.22 * 10^{3} \mathrm{M}^{-1} \mathrm{~cm}^{-1}\right)$ and the results were expressed as nmol of NADPH oxidized $/ \mathrm{min} / \mathrm{mg}$ of protein.

\section{Catalase}

The activity of catalase was assayed by the method described by Bisswanger (2004). To $0.98 \mathrm{ml} \mathrm{H}_{2} \mathrm{O}_{2}$ solution $(10 \mathrm{mM}), 0.2 \mathrm{ml}$ of plasma was added. Decrease in the absorption at $240 \mathrm{~nm}$ was followed. The catalase activity was calculated using the millimolar extinction coefficient of $\mathrm{H}_{2} \mathrm{O}_{2}\left(0.071 \mathrm{mmol} \mathrm{cm} \mathrm{cm}^{-1}\right)$ and the activity was expressed as micromoles of $\mathrm{H}_{2} \mathrm{O}_{2}$ oxidized per minute per milligram protein.

\section{Vitamin C}

Vitamin C level was evaluated by the method of Roe (1961). To $0.4 \mathrm{ml}$ of plasma/liver homogenate, $1.6 \mathrm{ml}$ of $10 \%$ TCA was added. The contents were mixed well and allowed to stand for 5 minutes. They were centrifuged at $2000 \mathrm{rpm}$ for 10 minutes. Blank and standard were also simultaneously processed with distilled water in the blank tube and the respective standard in the standard tube. To $1 \mathrm{ml}$ of the supernatant was added $0.4 \mathrm{ml}$ of DNPH reagent. The tubes were corked and incubated at $37{ }^{\circ} \mathrm{C}$ for three hours. After incubation period the tubes were kept in ice-bath and then $1.6 \mathrm{ml}$ of cold $65 \%$ $\mathrm{H}_{2} \mathrm{SO}_{4}$ was added. The contents were mixed and the color formed was read at $520 \mathrm{~nm}$ after 30 minutes. Liver protein was assayed by the method of Lowry et al. (1951).

\section{Statistical analysis}

Data was subjected to descriptive statistics and differences among the groups were analyzed using one way ANOVA. Tukey's test was run for multiple comparisons. Results were considered statistically significant at $\mathrm{p}<0.05$.

\section{RESULTS}

Acute toxicity

No mortality and gross change in the behaviour was observed for doses up to 500 $\mathrm{mg} / \mathrm{kg}$ body weight.

\section{Effects on body weight}

Body weight of rats in $\mathrm{AC}$ group was reduced as compared to the rats in $\mathrm{NC}$, EX1 and EX2 but the reduction was not statistically significant.

\section{Effects on marker parameters}

Levels of TBARS in EX1 and EX2 differ significantly from both AC and NC groups. EX1 had demonstrated $30 \%$ reduction in the levels of TBARS as compared to the levels in AC and the group EX2 demonstrated further decrease of approximately $60 \%$.

The activities of ALT and AST were significantly enhanced in AC $(\mathrm{p}<0.05)$ as compared to $\mathrm{NC}$ indicating the liver cell damage in this group (Table 1). The activities of these enzymes were significantly lowered in EX1 and EX2 $(p<0.05)$ as compared to group AC. The levels of ALT in EX1 differ significantly $(\mathrm{p}<0.05)$ from both AC and NC. It was $85.41 \pm 3.39 \mathrm{U} / \mathrm{L}$ in $\mathrm{AC}, 36.69 \pm 0.81$ $\mathrm{U} / \mathrm{L}$ in $\mathrm{NC}$ and $49.13 \pm 3.03 \mathrm{U} / \mathrm{L}$ in EX1. In case of AST, the levels in EX1, differ significantly from AC but the difference with NC was non significant. The levels of both enzymes in EX2 did not differ significantly from the levels in $\mathrm{NC}$ and this indicates towards the normalization of the liver structure in this group. The levels of total proteins in EX1 and EX2 differ significantly from AC (Table 1). It was $3.86 \pm 0.12$ in AC and $5.73 \pm 0.17 \mathrm{mg} / \mathrm{dl}$ in EX2. Differences with NC in both experimental groups were non significant.

\section{Effects on plasma anti-oxidants}

Effects of MBP administration on plasma antioxidants against alcohol induced toxicity are presented in Table 2 .

The results showed that the alcohol administration for 30 days had significant 
effects on plasma glutathione levels in both experimental groups as compared to AC. The levels in AC were significantly reduced $(\mathrm{p}<0.05)$ as compared to NC and EX1 and EX2. In EX1 and EX2, the levels of glutathione differed significantly from AC $(\mathrm{p}<0.05)$. The levels of GSH in EX2 were $45 \%$ higher than the levels in AC. In EX1 the levels were $17 \%$ higher than the levels in AC. The differences in EX2 when compared to NC were non significant but EX1 differed significantly $(\mathrm{p}<0.05)$ from $\mathrm{NC}$ even after 30 days of treatment.

The results of 30 days administration of MBP to albino rats resulted into the increased activities glutathione peroxidise in both experimental groups as compared to $\mathrm{AC}$ $(\mathrm{p}<0.05)$. In EX1 and EX2, differences with NC were non significant but the levels of glutathione peroxidase were still $25 \%$ higher in $\mathrm{NC}$ than the levels in EX1.

Levels of plasma vitamin $\mathrm{C}$ also showed similar trends. The levels of vitamin $\mathrm{C}$ in EX1 and EX2 differed significantly $(\mathrm{p}<0.05)$ when compared with $\mathrm{AC}$ and the difference with NC were non significant. The levels in AC showed 50\% reduction as compared to the levels in NC.

Activities of plasma catalase were significantly increased in EX1 and EX2 as compared to AC but the level of its activity did reach the normal state. Activities of plasma SOD showed slightly different pattern.
The differences in the activities of SOD were non significant in EX1 as compared to AC but it differed significantly $(\mathrm{p}<0.05)$ with NC. The differences in EX2 were significant $(p<0.05)$ when compared to both $\mathrm{NC}$ and $\mathrm{AC}$.

\section{Effects on liver antioxidants}

Effects of MBP administration on liver antioxidants against alcohol induced toxicity are presented in Table 2.

The results showed that MBP administration had maintained the levels of liver GSH in EX2 (EX2 vs NC = NS) but the differences were significant when compared with AC. Results of EX1 showed slightly different patterns. The levels of liver GSH in EX1 differed significantly from both NC and AC. The levels in EX1 were approximately $50 \%$ higher when compared with AC and 53\% less when compared with NC.

Levels of liver vitamin $\mathrm{C}$ in $\mathrm{EX} 1$ differed significantly from $\mathrm{NC}$ while the levels in EX2 differed significantly $(\mathrm{p}<0.05)$ from both $\mathrm{NC}$ and $\mathrm{AC}$.

Activities of liver catalase in both the experimental groups differ significantly from $\mathrm{NC}$ and AC $(\mathrm{p}<0.05)$. The activities of liver GPX show the same trend. Methanol extract administration affects activities of SOD differently. The differences in the levels of SOD in EX2 were non significant from NC while the levels in EX1 still differs significantly from $\mathrm{NC}(\mathrm{p}<0.05)$.

Table 1: Effects of Bauhinea purpurea methanol extract on marker parameters of alcohol induced toxicity in albino rats.

\begin{tabular}{lllll}
\hline Groups & $\begin{array}{l}\text { TBARS } \\
(\mathbf{n m o l} / \mathbf{d l})\end{array}$ & $\begin{array}{l}\text { AST } \\
(\mathbf{U} / \mathbf{L})\end{array}$ & $\begin{array}{l}\text { ALT } \\
(\mathbf{U} / \mathbf{L})\end{array}$ & $\begin{array}{l}\text { Total proteins } \\
(\mathbf{m g} / \mathbf{d l})\end{array}$ \\
\hline AC & $328.8 \pm 2.61$ & $58.41 \pm 2.39$ & $78.8 \pm 1.28$ & $3.76 \pm 0.12$ \\
NC & $64.29 \pm 3.7$ & $25.69 \pm 0.91$ & $45.3 \pm 1.87$ & $6.85 \pm 0.21$ \\
EX1 & $228.6 \pm 7.64^{\mathrm{ab}}$ & $37.13 \pm 3.63^{\mathrm{ab}}$ & $51.49 \pm 1.89^{\mathrm{a}}$ & $4.98 \pm 0.11^{\mathrm{a}}$ \\
& & & & \\
EX2 & $126.8 \pm 5.12^{\mathrm{ab}}$ & $35.37 \pm 2.71^{\mathrm{a}}$ & $42.49 \pm 1.28^{\mathrm{a}}$ & $5.93 \pm 0.17^{\mathrm{a}}$
\end{tabular}

TBARS: Thiobarbituric Acid Reactive Substances; AC = Alcohol control group administered alcohol (5 g/kg body weight ) every day; $\mathrm{NC}=$ Normal control group received distilled water every day; EX1 and EX2 are two experimental groups that received $50 \mathrm{mg}$ and $100 \mathrm{mg} / \mathrm{kg}$ body weight respectively for 30 days. Values are expressed as Mean $\pm \mathrm{SEM}, \mathrm{n}=5 \mathrm{in}$ each group; $\mathrm{a}=\mathrm{p}<0.05$ when compared with $\mathrm{AC} ; \mathrm{b}=\mathrm{p}<0.05$ when compared with $\mathrm{NC}$. 
Table 2: Effects of Bauhinea purpurea methanol extract on plasma antioxidants against alcohol induced toxicity in albino rats.

\begin{tabular}{|c|c|c|c|c|c|}
\hline Groups & $\begin{array}{l}\text { Plasma GSH } \\
\text { (mg/dl) }\end{array}$ & $\begin{array}{l}\text { Plasma VIT C } \\
\text { (mg/dl) }\end{array}$ & $\begin{array}{l}\text { Plasma GPX } \\
(\mathrm{mg} / \mathrm{dl})\end{array}$ & $\begin{array}{l}\text { Plasma CAT } \\
(\mathrm{U} / \mathrm{L})\end{array}$ & $\begin{array}{l}\text { Plasma SOD } \\
(\mathrm{U} / \mathrm{L})\end{array}$ \\
\hline $\mathrm{AC}$ & $32.36 \pm 3.61$ & $1.6 \pm 0.09$ & $3.47 \pm 0.61$ & $41.66 \pm 1.63$ & $16.89 \pm 1.52$ \\
\hline $\mathrm{NC}$ & $88.66 \pm 4.05$ & $2.88 \pm 0.13$ & $14.23 \pm 1.6$ & $85.13 \pm 3.78$ & $35.17 \pm 1.19$ \\
\hline EX1 & $42.9 \pm 3.26^{b}$ & $2.19 \pm 0.13^{\mathrm{a}}$ & $11.91 \pm 1.16^{\mathrm{a}}$ & $50.73 \pm 1.05^{\mathrm{ab}}$ & $25.47 \pm 0.96^{\mathrm{b}}$ \\
\hline $\mathrm{EX} 2$ & $62.04 \pm 2.63^{\mathrm{ab}}$ & $2.94 \pm 0.16^{\mathrm{a}}$ & $15.88 \pm 1.77^{\mathrm{a}}$ & $66.36 \pm 1.79^{\mathrm{ab}}$ & $28.27 \pm 1.32^{\mathrm{ab}}$ \\
\hline
\end{tabular}

Table 3: Effects of Bauhinia purpurea methanol extract on liver anti-oxidants against alcohol induced toxicity in albino rats.

\begin{tabular}{llllll}
\hline Groups & $\begin{array}{l}\text { Liver GSH } \\
\text { (mg/g of wet } \\
\text { tissue) }\end{array}$ & $\begin{array}{l}\text { Liver VIT C } \\
\text { (mg/g of wet } \\
\text { tissue) }\end{array}$ & $\begin{array}{l}\text { Liver GPX } \\
\text { (U/mg of } \\
\text { protein) }\end{array}$ & $\begin{array}{l}\text { Liver CAT } \\
\text { (U/mg of } \\
\text { protein) }\end{array}$ & $\begin{array}{c}\text { Liver SOD } \\
\text { (U/mg of } \\
\text { protein) }\end{array}$ \\
\hline $\mathrm{AC}$ & $27.88 \pm 2.22$ & $0.96 \pm 0.10$ & $16.84 \pm 1.24$ & $48.09 \pm 2.91$ & $32.37 \pm 0.73$ \\
$\mathrm{NC}$ & $99.88 \pm 3.78$ & $3.19 \pm 0.26$ & $32.1 \pm 1.25$ & $99.41 \pm 3.57$ & $64.62 \pm 2.37$ \\
$\mathrm{EX} 1$ & $46.37 \pm 2.07^{\mathrm{ab}}$ & $1.89 \pm 0.31^{\mathrm{b}}$ & $24.47 \pm 1.8^{\mathrm{ab}}$ & $68.69 \pm 2.11^{\mathrm{ab}}$ & $40.44 \pm 2.22^{\mathrm{b}}$ \\
& & & & & \\
$\mathrm{EX} 2$ & $77.19 \pm 3.74^{\mathrm{a}}$ & $2.32 \pm 0.23^{\mathrm{ab}}$ & $29.63 \pm 1.54^{\mathrm{a}}$ & $80.19 \pm 1.54^{\mathrm{ab}}$ & $50.61 \pm 0.8^{\mathrm{a}}$ \\
\hline
\end{tabular}

$\mathrm{AC}=$ Alcohol control group administered alcohol $(5 \mathrm{~g} / \mathrm{kg}$ body weight $)$ every day; $\mathrm{NC}=$ Normal control group received distilled water every day; EX1 and EX2 are two experimental groups that received $50 \mathrm{mg}$ and $100 \mathrm{mg} / \mathrm{kg}$ body weight respectively for 30 days. Values are expressed as Mean $\pm \mathrm{SEM}, \mathrm{n}=5$ in each group $\mathrm{a}=\mathrm{p}<0.05$ when compared with $\mathrm{AC} ; \mathrm{b}=\mathrm{p}<0.05$ when compared with NC.

\section{DISCUSSION}

Free radicals have aroused significant interest among scientists in the past decade and looking at different aspects of the causative agents of this damage. Metabolism of alcohol results into generation of free radical like ethyl and hydroxyl ethyl radicals (Lieber, 2004). Thus, alcohol induced hepatotoxicity is linked to oxidative stress because of generation of free radicals. Acetaldehyde formed during metabolism also reacts with macromolecules of hepatic cells and causes liver damage (Zima et al., 2001). In the present study MBP demonstrated its protective potential against alcohol induced liver toxicity as indicated by low levels of thiobarbituric acid, Serum aspartate aminotransferase (ALT), serum alanine aminotransferase (AST) and high levels of total protein. These findings are consistent the previous reports on other related species.

Thiobarbituric acid reactive substances (TBARS) are one of the marker indices of lipid peroxidation caused by oxidative stress and hence the increase in the levels of TBARS in liver and plasma is the direct reflection of oxidative injury of the liver tissue (Simoniello et al., 2010). There was a significant increase 
in the levels of both liver and plasma TBARS in $\mathrm{AC}$ that might be because of the oxidative stress caused by the generation of free radicals in alcohol metabolism (Nyblom, 2004). Administration of alcohol together with the MBP extract had significantly inhibited the oxidative stress generated by ethanol metabolism. This is indicated by the significant low levels of plasma and liver TBARS $(\mathrm{p}<0.05)$ in two experimental groups as compared to AC. Lipid peroxidation in cellular membranes in hepatic tissues causes severe damage and leakage of liver markers like ALT and AST into the circulation (Himerich et al., 2001). Level of total protein reduces significantly during oxidative damage as the liver is the central place for protein synthesis and the synthesis is halted during damage. In the present study low levels of ALT and AST and high levels of total proteins were recorded in experimental groups. These changes could be attributed towards the protective effects of MBP by inhibiting the lipid peroxidation.

Glutathione is a tripeptide present in all mammalian cells and participates in many metabolic processes for the protection of cells against free radicals and toxic metabolites (Nicotera, 1986). The decrease in the levels of reduced glutathione represents its increased utilization because of oxidative stress. This also serves as a substrate for the synthesis of glutathione-related enzymes. Reduced glutathione acts as a free radical scavenger, a regenerator of tocopherol, and plays an important role in the maintenance of protein sulfhydryl groups. Glutathione plays a central protective role against oxidative stress. Because of its free radical scavenging properties; the reduced glutathione is required for the metabolism of toxic metabolites to non toxic metabolite (Rojas, 1996). When the supply of glutathione is exhausted, free radical generated in alcohol metabolism can no longer be scavenged and hence causes lipid peroxidation that result into hepatic cell damage. Excessive alcohol consumption leads to deficiency of anti-oxidants like vitamin C and reduced glutathione (Gerster, 1995) and this could be the reason for low levels of these anti-oxidants in liver and plasma of AC. Vitamin $\mathrm{C}$ has the ability to sequester the singlet oxygen radical, stabilize the hydroxyl radical and thus halt peroxidation of cellular lipid membranes (Rojas, 1994). In the present study also, levels of vitamin C were maintained high in all experimental groups. These could be attributed to anti-oxidants present in MBP. It appears that antioxidants present in the extract are actively neutralizing free radicals which are helping maintain the elevated levels of non-enzymatic anti-oxidants like vitamin $\mathrm{C}$ and reduced glutathione (Noctor et al., 1998; Miglani et al., 2003).

Super oxide dismutase catalyzes the dismutation of super oxide into oxygen and hydrogen peroxide and thus prevents the deleterious effects of superoxide radicals (Culotta, 2000). Both the enzymes, catalase and glutathione peroxidase are responsible for reducing hydrogen peroxide to water (Husain and Somani, 1997). Thus catalase helps in neutralizing the toxic effect of hydrogen per oxide and protects the cells from oxidative damage. The glutathione redox cycle is a central mechanism for reduction of hydroperoxides to water by oxidizing reduced glutathione to oxidized form which in turn is reduced to reduced glutathione by glutathione reductase. An increase in the production of super oxide dismutase without a subsequent elevation of catalase or glutathione peroxidase leads to the accumulation of hydrogen peroxide. Hydrogen peroxide on accumulation gets converted into the hydroxyl radical which is a very reactive species. In the present study, activities of SOD were enhanced in both the groups but in group EX2 only the significant enhancement was noted. But the activities of catalase and glutathione peroxidise were significantly increased in both the experimental groups as compared to group AC. Thus the activities of these three non enzymatic anti-oxidants are in pace with each other. This indicates that, MBP maintains an intricate balance between these enzymes to prevent the oxidative stress and over accumulation of $\mathrm{H}_{2} \mathrm{O}_{2}$ in the system. $B$. 
purpurea has been reported to possess tocopherols and phenols (Foti, 2007). Thus there is a possibility that the anti oxidant and hepatoprotective effects of MBP are because of its richness in anti-oxidants like tocopherol and phenol as phenols are reported to possess strong antioxidant properties. The present finding is consistent with the previous findings of other species of the genus Bauhinea.

\section{Conclusion}

Methanol extract of $B$. purpurea imparts its protective effects in alcohol induced oxidative stress by preventing lipid peroxidation.

\section{ACKNOWLEDGEMENTS}

Author is thankful to Office of Research and Development, University of Botswana, for providing fund to carry out this research.

\section{REFERENCES}

Ambasta SP. 1998. The Wealth of India, Raw Materials (Vol. 2). Publication and Information Directorate, CSIR: B. New Delhi; 56-57.

Bisswanger H. 2004. Practical Enzymology Wiley-VCH; 79.

Bodakhe B, Jayakar B, Ram A. 2007. Hepatoprotective properties of Bauhinia variegata bark extract. Yakugaku Zasshi., 127: 503-507.

Culotta VC. 2000. Superoxide dismutase, oxidative stress, and cell metabolism. Curr Top Cell Regu.l, 36: 117-132.

Ellman GC. 1959. Tissue sulfhydryl groups. Arch Biochem Biophys., 82: 70-77.

Firdous AP, Sindhu ER, Kuttan R. 2011. Hepato-protective potential of carotenoid meso-zeaxanthin against paracetamol, $\mathrm{CCl} 4$ and ethanol induced toxicity. Indian J. Exp. Biol., 49(1): 44-49.

Foti MC. 2007. Antioxidant properties of phenols. Journal of Pharmacy and Pharmacology, 59(13): 1673-1685.

Gerster H. 1995. $\beta$-carotene, vitamin $E$ and vitamin $\mathrm{C}$ in different stages of experimental carcinogenesis. Eur. J. Clin. Nutr., 49: 155168.

Himmerich H, Anghelescu I, Klawe C, Szegedi A. 2001. Vitamin B12 and hepatic enzyme serum levels correlate in male alcohol dependent patients. Alcohol, 36(1): 26-28.

Husain K, Somani SM. 1997. Interaction of exercise and ethanol on hepatic and plasma antioxidant system in rat. Pathophysiol., 4: 69-74.

Jeannot E, Pogribny IP, Beland FA, Rusyn I. 2011. Chronic administration of ethanol leads to an increased incidence of hepatocellular adenoma by promoting $\mathrm{H}$ ras-mutated cells. Cancer Lett., 301(2): 161-167.

Johnston CS, CG Meyer CG, Srilakshmi JC. 1993. Vitamin C elevates red blood cell glutathione in healthy adults. American $J$ Clin Nutr., 58: 103-105.

Kakkar P, Das B, Viswanathan PN. 1984. A modified spectrophotometric assay of superoxide dismutase. Indian J Biochem Biophy., 21: 130-132.

Kirtikar KR, Basu BD. 2001. Indian Medicinal Plants (Vol III). Oriental Enterprizes: Dehradun.

Knockaert L, Descatoire V, Vadrot N, Fromenty B, Robin MA. 2010. Mitochondrial CYP2E1 is sufficient to mediate oxidative stress and cytotoxicity induced by ethanol and acetaminophen. Toxicol. in Vitro, 25(2): 475-484.

Lieber CS. 2004. Alcoholic fatty liver: its pathogenesis and mechanism of progression to inflammation and fibrosis. Alcohol, 34(1): 9-19.

Lowry AH, Rosenbrough MJ, Farr AL, Randall RJ. 1951. Protein measurement with Folin-Phenol reagent. J. Biol. Chem., 193: $265-275$.

Miglani A, Seth RK, Siwach SB. 2003. Effect of vitamin $\mathrm{C}$ supplementation on reduced glutathione and malondialdehyde in patients with acute myocardial infarction. Clin Chim Acta., 327: 187-188.

Nageshwar G, Anuradha SMJ, Radhakrishaniah, Narayan LL. 1986. 
Distribution pattern of phenolic constituents in species of Bauhinea Linn and its taxonomic significance. Proc Indian Acad Sci (Plant Sci), 96(1): 1-7

Nicotera P, Orrenius, S. 1986.Role of thiols in protection against biological reactive intermediates. Adv Exp Med Biol., 176: 267-274.

Noctor G, Foyer CH. 1998. Ascorbate and glutathione: Keeping Active Oxygen Under Control. Annu Rev Plant Physiol Plant Mol Biol., 49: 249-279.

Nyblom H, Berggren U, Balldin J, Olsson R. 2004. High AST/ALT ratio may indicate advanced alcoholic liver disease rather than heavy drinking. Alcohol, 39(4): 336339.

Paglia DE, Valentine WN. 1967. Studies on the quantitative and qualitative characterization of erythrocyte glutathione Peroxidase. J Lab Clin Med., 70: $158-169$

Panda S, Kar A. 1999. Withania somnifera and Bauhinia purpurea in the regulation of circulating thyroid hormone concentrations in female mice. $J$ Ethanopharmacol., 67(2): 233-239.

Roe JH. 1961. Methods of Biochemical analysis (Vol. 1). Glicks Edition, Interscience Publishers Inc: New York; 115-139.

Rojas C, Cadenas S, Perez -Campo R, LopezTores M, Barja G. 1994. Effect of vitamin $\mathrm{C}$ on antioxidants, lipid peroxidation, and GSH system in the normal guinea pig heart. J Nutr Sci., 40(5): 411-20.

Rojas C, Cadenas S, Lopez-Tores M, Perez Campo R Barja G. 1996. Increase in heart glutathione redox ratio and total antioxidant capacity and decrease in lipid peroxidation after vitamin E dietary supplementation in guinea pigs. Free Radic Biol Med., 21(7):.907-15.

Sallie R, Tredger JM, William R. 1991. Drugs and the liver. Part 1: Testing liver function. Biopharm Drug Dispos., 12: 251-259.
Sharanabasappa GK, Santosh MK, Shaila D, Seetharam YN, Sanjeevrao I. 2007. Phytochemical Studies on Bauhinia racemosa Lam.Bauhinia purpurea Linn. and Hardwickia binata Roxb. E-Journal of Chemistry, 4(1): 21-31.

Silva EG, Behr GA, Zanotto-Filho A, Lorenzi R, Pasquali MA, Ravazolo LG, Bordignon CL Jr, Silva FA, Aboy AL, Bassani VL, Henriques AT, Reginatto FH, Dal-Pizzol F, Moreira JC. 2007. Antioxidant activities and free radical scavenging potential of Bauhinia microstachya (RADDI) MACBR. (Caesalpinaceae) extracts linked to their polyphenol content. Biological \& Pharmaceutical Bulletin, 30(8): 14881496.

Simoniello MF, Kleinsorge EC, Scagnetti JA, Mastandrea C, Grigolato RA, Paonessa AM, Carballo MA. 2010. Biomarkers of cellular reaction to pesticide exposure in a rural population. Biomarkers, 15(1): 5260.

Tripathi YB, Upadhyay AK, Chaturvedi P. 2001. Antioxidant properties of Smilax china. Ind J Exp Biol., 39: 1176-1179.

Zakaria ZA, Abdul Rahman NI, Loo YW, Abdul Ayub AH, Sulaiman MR, Gopalan HK, Fatimah CA. 2009. Antinociceptive, anti-inflammatory activities of chloroform extract of Bauhinia purpurea leaves in animal model. International Journal of Tropical Medicine, 4(4): 140145.

Zima T, Fialova L, Mestek O, Janebova M, Crkovska J, Malbohan I, Stipek S, Mikulikova L., Popov P. 2001. Oxidative stress, metabolism of ethanol and alcohol related disease. J. Biomed. Sci., 8(1): 5970. 